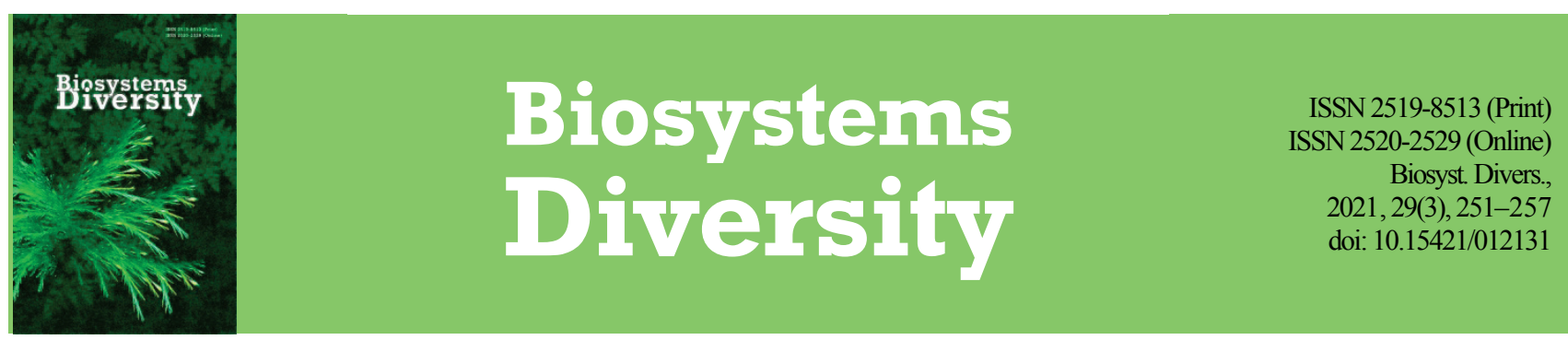

\title{
Prevalence of gastrointestinal helminths in ruminants in Ukraine: a 5-year meta-analysis
}

\author{
O. V. Kruchynenko, S. M. Mykhailiutenko, M. A. Petrenko, L. M. Kuzmenko
}

Poltava State Agrarian Academy, Poltava, Ukraine

\section{Article info \\ Received 01.07.2021 \\ Received in revised form \\ 28.07.2021 \\ Accepted 29.07.2021 \\ Poltava State \\ Agrarian Academy, \\ Skovorodyst., 1/3, \\ Poltava, 36003, \\ Ukraine. Tel. \\ +38-099-062-64-96 \\ E-mail: \\ oleg.kruchynenko@, \\ pdaa.edu.ua}

\section{Kruchynenko, O. V., Mykhailiutenko, S. M., Petrenko, M. A., \& Kuzmenko, L. M. (2021). Prevalence of gastrointestinal helminths in ruminants in Ukraine: A 5-year meta-analysis. Biosystems Diversity, 29(3), 251-257. doi:10.15421/012131}

The production of environmentally friendly livestock products is currently receiving much attention, especially in the European Union. The problem of monitoring the quality and safety of meat and milk in modern conditions is relevant not only for Ukraine but also for the world community. The scientific substantiation of the methods of research on meat for sale subject to invasive diseases is especially important, as the product may pose risks to the consumer. One of the criteria for assessing the welfare of a herd is the prevalence of helminthiases in cattle. Ruminant parasitoses in Ukraine have always been and remain a separate, often significant, problem for veterinary specialists. Helminths have evolved to use a wide range of ecological niches. In this study, we tried to quantify the prevalence of helminthiases among ruminants (cattle, sheep and goats) in Ukraine. The relevant studies were searched for in the online databases. The meta-analysis included 15 publications from January 2015 to December 2020 which reported the spread of parasites in Ukraine. The research results show that the infestation of ruminants with gastrointestinal helminths on the territory of Ukraine is $56.7 \%$. Egger's regression test revealed no significant publication bias. During the period of pastured farming, stable parasitocenoses are formed in the body of ruminants. The parasitoses are caused by helminths (gastrointestinal strongyles, liver flukes, paramphistomas, dicrocelia). They are recorded in monoinvasions or mixed invasions. Ruminants, according to helminthological examination in different climatic zones, are constantly infested with trematodes. In Ukraine, the presence of three species of flukes has been confirmed in ruminants: Fasciola hepatica, Dicrocoelium dendriticum and Paramphistomum cervi. Parasitization by those species negatively affects the profitability of dairy farming. Trematodes cause significant economic losses: reduced milk productivity of cows, reduced live weight gain of young animals, negative impact on reproduction. At the same time, fascioliasis is socially significant and dangerous to humans. According to the analyzed literature sources, two types of cestodes have been registered in Ukraine: Moniezia benedeni and M. expansa. The epizootic situation regarding nematodes is just as fraught. That is the most numerous group of helminths, their fauna is represented by the following species: Strongyloides papillosus, Nematodirus spathiger, Bunostomum spp., Oesophagostomum radiatum, Haemonchus contortus, Toxocara vitulorum, Trichuris skrjabini, T. ovis and T. globulosa. It is proven that in cattle parasitocenoses are recorded more often than monoinvasions. The highest rates of prevalence of infection were observed when polyinvasion included gastrointestinal strongyles, namely from the order Strongylida. Strongyloides papillosus is the most common taxonomic representative, while Fasciola hepatica has the lowest prevalence of infection, especially in sheep. Updated data on helminthiasis will expand the screening strategy to maintain the health of farm ruminants and reduce economic losses.

Keywords: cattle; sheep; goats; Trematoda; Cestoda; Nematoda.

\section{Introduction}

Despite preventive measures, gastrointestinal helminthiases of ruminants are widespread. Stable parasitocenoses of helminths (gastrointestinal strongylates, fascioles, dicrocelia, paramphistomas, cestodes) and protozoa are formed in the body of cattle. An analysis of publications over the past five years confirms the circulation of pathogens in the world (Akca et al., 2014; Jones et al., 2017; Karshima et al., 2018; Squire et al., 2018; Scala et al., 2019). Fascioliasis is the most common disease caused by trematodes of cattle, sheep and goats. Its pathogens are Fasciola hepatica L., 1758 and $F$. gigantica Cobbold, 1855 . However, according to some researchers, in nature there are not only the above species, but also their hybrids (Amer et al., 2016; Aghayan et al., 2019). Fasciola spp., according to publications, are found on five continents of the globe, in more than 50 countries (Mehmood et al., 2017). In particular, Fasciola is common in Iran. There, the prevalence of fasciolosis did not exceed $9.0 \%$ in cattle, $4.2 \%$ in sheep and $3.1 \%$ in goats, respectively (Khademvatan et al., 2019). Another team of scientists conducted a meta-analysis of this disease, finding the incidence to be $21.0 \%$ in cattle, $2.4 \%$ in sheep and $2.0 \%$ in goats (Soosaraei et al., 2020). The highest rates of Fasciola spp. infection, 10.8\%, is reported in slaughter animals of the province of Gilan (Ghanimatdan et al., 2019). Recent molecular genetic studies have not found any hybrid forms of Fasciola in southeastern Iran (Mirahmadi et al., 2018).
Yuan et al. (2015) conducted research on Fasciola in China. The authors indicate that fascioliasis in goats is widespread at the level of $3.5 \%$ to $37.0 \%$, with the average number of eggs in $1 \mathrm{~g}$ of feces $\mathrm{EPG}=$ 29.0-166.0. At the same time, the prevalence in cattle ranged from $13.3 \%$ to $46.2 \%$ with average $\mathrm{EPG}=36.4-100.0$. In Europe, including the Russian Federation, fascioliasis infection has also been reported among ruminants (Bennema et al., 2009; Kuerpick et al., 2012; Beesley et al., 2018). A sharp decrease to $2.2 \%$ is found in the prevalence of trematodes in cattle, in particular in Tyumen region (Siben et al., 2018). Some scientific reports suggest that among cattle, Fasciola spp. are recorded less often in sheep and goats (Abdulhakim \& Addis, 2012; Abdolali et al., 2016; Pinilla et al., 2020). According to other studies, fascioliasis is more common in sheep and goats (Huklaeva, 2009; Gazimagomedov \& Ataev, 2011; Taye et al., 2016; Pinilla León et al., 2019). Fascioliasis has been shown to cause significant economic damage to livestock farms (Jaja et al., 2017; Arbabi et al., 2018; Arias-Pacheco, 2020). Global livestock losses caused by fascioliasis are more than $\$ 3$ billion per year (Rinaldi et al., 2015; Elelu \& Eisler, 2017; Mehmood et al., 2017).

Numerous publications have confirmed the presence of zoonotic foci of another dangerous trematode disease in the world, namely dicroceliasis (Majidi-Rad et al., 2018; Shamsi et al., 2020). To date, three pathogens are known: Dicrocoelium dendriticum (Rudolphi, 1819), D. hospes (Looss, 1907) and D. chinensis (Sudarikov and Ryjikov, 1951) (Maurelli et al., 
2007; Otranto et al., 2007; Gorjipoor et al., 2013). There are scientific reports of the spread of Dicrocoelium spp. in cattle in Nigeria (Elelu \& Eisler, 2017) and Algeria (Chougar et al., 2019). In cattle, sheep and goats on farms in Iran, Dicrocoelium infection has also been recorded (Arbabi et al., 2011; Khanjari et al., 2014; Mohamadzadeh et al., 2016; Majidi-Rad et al., 2018). Dicrocoelium dendriticum has been recorded in Saudi Arabia, for example, the prevalence was $0.5 \%$ in imported sheep (Albogami et al., 2015). In Sardinia, D. dendriticum was found on average in $25.5 \%$ of animals on sheep farms (Scala et al., 2019). Dicroceliasis has been observed in the Russian Federation, the rate of prevalence in cattle ranging from $0.1 \%$ to $20.6 \%$ (Shmakova, 2019).

The problem of Paramphistomum infections of animals is not new and has been studied for a long time (Hanna et al., 1988, Huson et al., 2017). Scientists have identified more than 70 species from the superfamily Paramphistomoidea in ruminants globally (Sanguankiat et al., 2016; Ali et al., 2018; Kahl et al., 2021). Thus, according to researchers, three species have been registered in Uttarakhand, India: Paramphistomum cervi, Gastrothylax crumenifer and Fischoederius elongates (Maitra et al., 2014). Also, Chaoudhary et al. (2014) confirmed the parasitism of $\mathrm{Pa}$ ramphistomum cervi in sheep in the state of Gujarat, western India. Coprological studies have established the rates of prevalence in sheep (16.3\%) and goats (13.6\%) (Godara et al., 2014). Calicophoron daubneyi is found in cattle and sheep kept in Wales, Western Europe (Jones et al., 2017). In Ethiopia, bovine helminthiasis was diagnosed, on average, in 51.8\% of slaughtered animals (Ayalew et al., 2016). According to researchers, $30.0 \%$ of cattle were affected by Paramphistomum spp. in Bangladesh (Ahmed et al., 2015). At the same time, quite high rates of infection were recorded in goats $(\approx 73.0 \%)$. Polyinfections, made up by different species of amphistomes (Paramphistomum cervi, Cotylophoron cotylophorum and Gastrothylax crumenifer), were found in $60.0 \%$ of goats (Uddin et al., 2006). In Iran, the following species were found in cattle: Paramphistomum cervi (13.3\%), Cotylophoron cotylophorum (19.5\%), Gastrothylax crumenifer (5.9\%) and Carmyerius spatiosus (2.7\%) (Hajipour et al., 2021). The overall prevalence among domesticated animals did not exceed $9.7 \%$. Also, cattle were found to be more prone to paramphistomosis than sheep and goats. Similar results were obtained by scientists from Ireland. According to their research, cattle have a higher risk of paramphistomosis than sheep and goats (Naranjo-Lucena et al., 2018).

Among cestodes of ruminants, one of the most common is Moniezia. The genetic diversity of Moniezia spp. was confirmed in ruminants (Diop et al., 2015). According to Nguyen et al. (2012), M. benedeni is more common in cattle, and M. expansa in sheep and goats. The work of other scientists also proves that $M$. benedeni predominates in cattle (Irie et al., 2013). The rate of prevalence of anoplocephalic cestodes was $47.4 \%$ in sheep, and only $6.2 \%$ in goats. The diseases occurred not as monoinfections. At the same time, the species composition of cestodes was determined. Thus, in sheep they are represented by Avitellina centripunctata (38.7\%), M. expansa (15.4\%), Stilesia globipunctata (16.7\%) and Thysaniezia ovilla $(0.4 \%)$. The goats were infected with M. expansa $(6.2 \%)$ and T. ovilla $(2.1 \%)$ (Ndom et al., 2016).

In Sri Lanka, the recorded parasites of cattle include hookworms ( $\mathrm{Bu}$ nostomum spp.), whipworms (Trichuris spp.), digenetic trematodes ( $\mathrm{Pa}$ ramphistomum spp.), cestodes (Moniezia spp.) (Gunathilaka et al., 2018). In South Africa, goats are parasitized by Trichuris spp., Strongyloides papillosus, Moniezia spp., and Strongylata spp. On average, prevalence rate did not exceed 37.1\% (Mpofu et al., 2020). The following genera of nematodes were found in sheep in Southwestern Serbia: Ostertagia, Trichostrongylus, Nematodirus, Haemonchus contortus, Oesophagostomum, Chabertia ovina, Cooperia, Marshallagia, Skrjabinema and Bunostomum. Parasitosis was observed in $82.6 \%$ of animals (Pavlović et al., 2017). From May 2014 to April 2015, the parasitofauna of ruminants was studied in Sohag (Egypt). The prevalence of helminths averaged $47.5 \%$ in cattle, $30.0 \%$ in buffaloes, and $50.3 \%$ in sheep. The dominant nematodes belonged to the family Trichostrongylidae (Al-Aboody et al., 2016).

Studies in Northeastern Colombia have confirmed the circulation in ruminants of parasites such as Eimeria spp., Fasciola hepatica and helminths of the order Strongylida. The prevalence in sheep was higher $(63.0 \%)$ than in cattle $(50.5 \%)$ and, accordingly, the pathogens of the Strongylida order predominated in sheep $(31.9 \%)$ compared to cattle
(16.5\%) (Pinilla Leon et al., 2019). The following species of parasites have been identified on Portuguese sheep farms: Nematodirus spp., Skrjabinema spp., Moniezia expansa, M. benedeni, Trichuris spp., Capillaria spp., Eimeria spp., Dicrocoelium spp. and Fasciola hepatica (Ruano et al., 2020). Given the above, the purpose of our study was to conduct a metaanalysis of the prevalence of gastrointestinal helminthiasis in Ukraine in 2015-2020.

\section{Material and methods}

The study followed the Preferred Reporting Items for Systematic Review and Meta-Analysis (PRISMA) guidelines published in (Moher et al., 2009). From January 2015 to December 2020, two authors (O. V. Kruchynenko and S. M. Mykhailiutenko) independently searched for publications in English and Ukrainian. The prevalence of gastrointestinal helminths in ruminants in Ukraine was assessed using Scopus, PubMed, Science Direct, Web of Science and Google Scholar databases. The search was performed by keywords: prevalence, gastrointestinal helminths, Fasciola hepatica, Dicrocoelium dendriticum, Paramphistomum spp., Moniezia spp., Strongylida, Strongyloides papillosus, Trichuris spp., cattle, sheep, goats, Ukraine. The exclusion criteria included: 1) identified publications that duplicated each other; 2) the total number of studied animals (less than 90); 3) inability to determine the exact number of positive cases and the total number of examined animals. Later, differences in the individual findings of authors were resolved through discussion and consensus with a third author (M. A. Petrenko). The meta-analysis included 15 publications (Fig. 1).

The data required in analysis included the author's name, year of study and year of publication, sample size, number of positive cases, status and region of study, study design, study type, species of host and helminth, determination of host and animal at least to the genus level. Preliminary analysis, including summation, subtraction and division, was performed using Microsoft Excel 2016. Statistical and meta-analysis were carried out with Jamovi 1.6 (The Jamovi Project, 2021). Prevalence for individual studies was determined by multiplying the ratio of cases to sample size by 100 . The binomial formula $95 \% \mathrm{CI}=\mathrm{p} \pm \mathrm{zl}-\alpha / 2 \sqrt{ } \mathrm{p}(1-\mathrm{p} / \mathrm{n})$ was employed to determine the $95 \%$ confidence interval ( $95 \% \mathrm{CI})$. It was assumed that the true effect sizes might differ within eligible studies; therefore, the random-effects model was used to determine pooled prevalence estimates (Hedges \& Vevea, 1998). Heterogeneity within studies was evaluated using the Cochran's Q-test while percentage variation in prevalence estimate due to heterogeneity was quantified using the formula $\mathrm{I}^{2}=$ $100 \times(\mathrm{Q}-\mathrm{df}) / \mathrm{Q}$, where $\mathrm{Q}$ is Chi square and df is the degree of freedom which is the number of studies minus one. According to Higgins \& Thompson (2002), $\mathrm{I}^{2}$ values of $0,25,50$ and $75 \%$ were considered as no, low, moderate and high heterogeneities, respectively. Representation of included studies based on effect size and CI was illustrated by forest plot diagram. Confidence intervals of $95 \%$ of the distribution of gastrointestinal helminths of ruminants were calculated in Open Source Epidemiologic Statistics for Public Health, Version 3.01, updated 2013/04/06 (www.openepi.com).

\section{Results}

The existing descriptive approach to the synthesis of information in veterinary medicine currently has a major drawback - the lack of systematicity; descriptive reviews do not use strict scientific methods, which are usually used in the presentation of research data. As a result, such publications are difficult to reproduce, they only partially reflect the subjective opinion of their authors. Thus, of the 34 studies obtained, nineteen were removed after scanning the titles, making a detailed review of the abstract and establishing the lack of a clearly defined number of positive cases or sample sizes. A total of 15 studies were included in the meta-analysis. The process of selecting research data for the included publications and the list of excluded ones is presented in Figure 2. We analyzed the materials of articles published in 2015-2020. Mostly $(n=8)$ the research was conducted in the Central Ukraine (Table 1). Ten publications determined the prevalence of helminthiasis in sheep only. Four publications were devoted to the study of bovine parasitosis, only three studies were conducted on goats. 


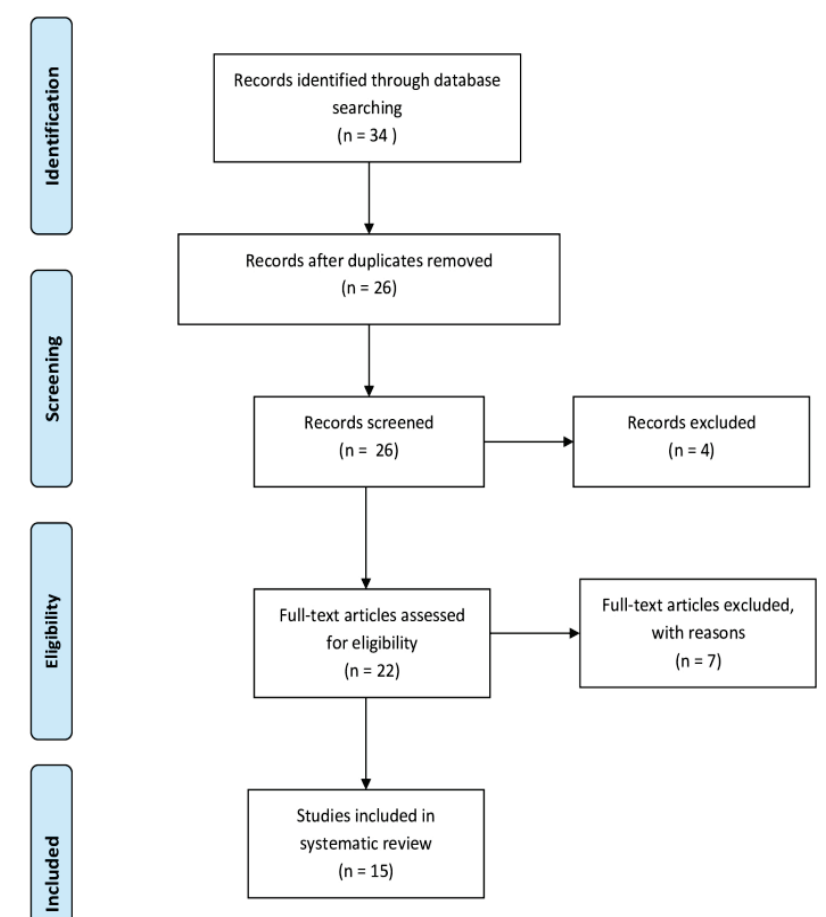

Fig. 1. Flow diagram for the selection process of eligible studies for the meta-analysis

A total of 19,389 positive cases were recorded from a sample of 34,060. The biological material collected during the individual studies included faeces or helminths detected during autopsy (Fig. 2). The overall prevalence of gastrointestinal helminths was $56.7 \%$ (95\% CI: 56.2-57.3). Hence, among the study regions the ruminant helminthiases are most prevalent in the central Ukraine. Polyinfections dominate over monoinfections (Table 2). Estimation of prevalence and heterogeneity. The studies included in the meta-analysis were high heterogenous, $\mathrm{I}^{2}=99.8 \%(\mathrm{P}<$ 0.001). Based on Egger's regression test, there was no significant publication bias $(\mathrm{P}=0.534)$ the forest plot diagram of current meta-analysis (Fig. 3). Most of the analyzed work is devoted to animal diseases in Central Ukraine. The studies are descriptive and not generalized in systematic reviews and meta-analyses.

The black boxes sizes are proportional to the study weight, with the lines indicating $95 \%$ confidence intervals (CIs).

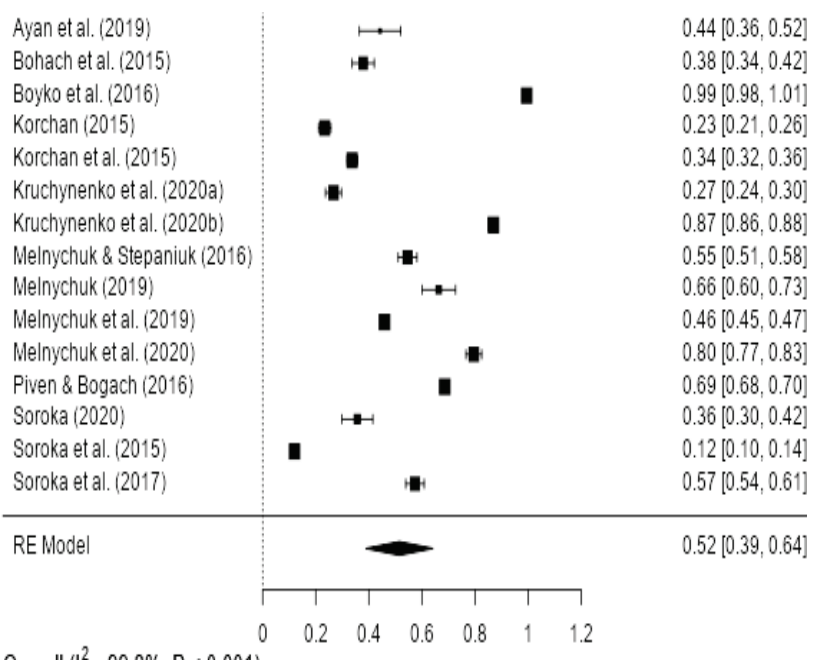

Fig. 2. Forest plot of prevalence of helminths among domestic ruminants in Ukraine

Table 1

Summary of the main characteristics of included studies in the meta-analysis

\begin{tabular}{|c|c|c|c|c|c|c|}
\hline Source of literature & Region & Host & Method of diagnosis & Sample size & Cases & Prevalence $(\%)$ \\
\hline Ayan et al. (2019) & - & sheep & microscopy & 156 & 69 & 44.2 \\
\hline Bohach et al. (2015) & South & sheep & microscopy & 520 & 197 & 37.9 \\
\hline Boyko et al. (2016) & Central & sheep & microscopy & 98 & 98 & 100.0 \\
\hline Korchan (2015) & Central & goats & microscopy post mortem & 1253 & 293 & 23.4 \\
\hline Korchan et al. (2015) & Central, East, South & goats & microscopy & 2290 & 772 & 33.7 \\
\hline Kruchynenko et al. (2020a) & Central & cattle, sheep, goats & post mortem & 832 & 222 & 26.6 \\
\hline Kruchynenko et al. (2020b) & Central & cattle & microscopy post mortem & 6660 & 5791 & 86.9 \\
\hline Melnychuk \& Stepaniuk (2016) & Central & sheep & microscopy & 760 & 415 & 54.6 \\
\hline Melnychuk (2019) & South & sheep & post mortem & 214 & 142 & 66.3 \\
\hline Melnychuk et al. (2019) & Central, South-Eastern & sheep & microscopy & 9787 & 4494 & 45.9 \\
\hline Melnychuk et al. (2020) & Central, South-Eastern & sheep & post mortem & 710 & 565 & 79.6 \\
\hline Piven \& Bogach (2016) & South & sheep & microscopy & 8151 & 5593 & 68.6 \\
\hline Soroka $(2020)$ & North & sheep & microscopy & 258 & 92 & 35.7 \\
\hline Soroka et al. (2015) & South & cattle & microscopy post mortem & 1701 & 204 & 11.9 \\
\hline Soroka et al. (2017) & North & cattle & microscopy & 770 & 442 & 57.4 \\
\hline Overall & - & - & - & 34160 & 19389 & 56.7 \\
\hline
\end{tabular}

Table 2

Pooled prevalence estimates and distribution of helminths species according to class of parasites

\begin{tabular}{|c|c|c|c|c|c|c|}
\hline \multirow{2}{*}{ Group } & \multirow{2}{*}{ Parasite species } & \multirow{2}{*}{$\begin{array}{l}\text { Number } \\
\text { of studies }\end{array}$} & \multicolumn{3}{|c|}{ Pooled prevalence estimates } & \multirow{2}{*}{$(95 \% \mathrm{Cl})$} \\
\hline & & & sample size & cases & prevalence, $\%$ & \\
\hline \multirow{3}{*}{ Trematodes } & Fasciola hepatica Linnaeus, 1758 & 2 & 6768 & 673 & 9.9 & $9.2-10.7$ \\
\hline & Dicrocoelium dendriticum (Rudolphi, 1819) & 5 & 10602 & 2010 & 18.9 & $18.2-19.7$ \\
\hline & Paramphistomum spp. (Fischoeder, 1901) & 1 & 6660 & 1034 & 15.5 & $14.7-16.4$ \\
\hline Cestodes & Moniezia spp. & 2 & 8384 & 5641 & 67.3 & $66.3-68.3$ \\
\hline \multirow{3}{*}{ Nematodes } & Strongyloides papillosus (Wedl, 1856) & 1 & 98 & 98 & 100.0 & $96.2-100.0$ \\
\hline & $\begin{array}{l}\text { Strongylida: Bunostomum, Oesophagostomum, Nematodirus, Chabertia, } \\
\text { Cooperia, Trichostrongylus, Ostertagia, Haemonchus }\end{array}$ & 7 & 19287 & 12047 & 62.5 & $61.8-63.1$ \\
\hline & Trichuris spp. & 2 & 3607 & 811 & 22.5 & $21.1-23.9$ \\
\hline
\end{tabular}

Note: for helminths of the order Strongylida, genera are given. 


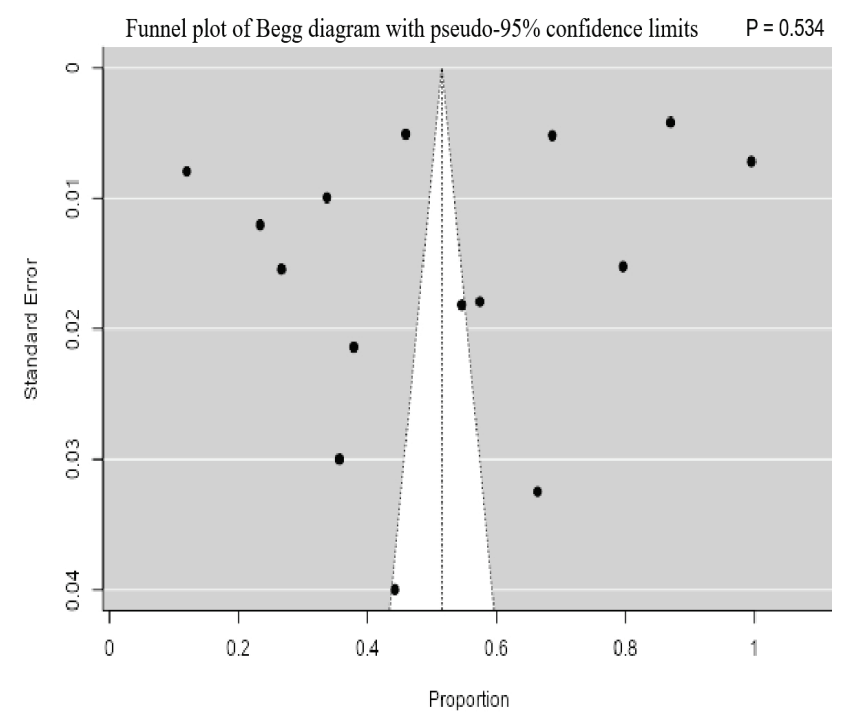

Fig. 3. Funnel plot for the studies included in meta-analysis

Black dots are publications, included in the meta-analysis. The $\mathrm{x}$ axis indicates the prevalence of helminths, and the y axis shows the standard error of distribution $(\mathrm{P}>0.05$ indicates no publication error).

\section{Discussion}

It is important for scientists and practitioners to understand and implement the principles of confirmation and objectivity in research, using tools such as systematic review and meta-analysis, which are already regularly used worldwide (Brown, 2002; Sargeant \& O'Connor, 2020). We conducted the first meta-analysis on the prevalence of gastrointestinal helminthiasis in ruminants in Ukraine. This research is extremely relevant because it provides useful epidemiological information needed to reduce economic losses in livestock. Based on 15 publications, the total prevalence of helminthiases of the gastrointestinal tract is $56.8 \%$ (95\% CI: 56.2-57.3). In our work, the studies included in the meta-analysis were highly heterogenous, $\mathrm{I}^{2}=99.9 \%(\mathrm{P}<0.001)$. Karshima et al. (2018) found that the average prevalence of helminthiases in Nigeria was $7.5 \%$ between 1970 and 2016 (95\% CI: 7.38-7.57\%). The level of heterogeneity was $\mathrm{I}^{2}=99.8 \%$. Fasciola gigantica had the widest geographical distribution. According to the systematic analysis, the total prevalence of fasciolosis was $6.2 \%$ in Iran in 1999-2019 (95\%, CI $=5.8-6.5 \%$ ) (Khademvatan et al., 2019). Another group of scientists from Iran for the period of 2000 2016 indicate that the $2.6 \%$ prevalence of fascioliasis among animals. In Ukraine, the equivalent figure was $9.9 \%$ in 2015-2020. Soosaraei et al. (2020) also diagnosed high heterogeneity $\left(\mathrm{I}^{2}=99.96 \%\right)$. The data of the meta-analysis showed a decrease of fascioliasis among sheep and goats in Iran.

At the same time, there are very few reports of fascioliasis in sheep and goats in Ukraine. One of the publications mentions the helminth fauna of sheep and goats of Dnipropetrovsk region, and notes only $F$. hepatica in sheep and goats (Bojko, 2015). Fascioliasis in sheep as a part of mixed infection (Piven \& Bogach, 2016) is also recorded in Odesa region. No other data could be found on the parasitism of $F$. hepatica in sheep and goats on Ukrainian farms. Sheep, goats and cattle grazing on pastures are constantly infected by other trematodes (Godara et al., 2014; Kahl et al., 2021). In Ireland, pathogens of the genus Paramphistomum spp. affected $52.0 \%$ of cattle and from $14.0 \%$ in sheep. In sheep farms of Sardinia, D. dendriticum is on average found in $25.5 \%$ of animals (Scala et al., 2019). The pathogen is also registered in the Russian Federation. There, the prevalence of these helminths in cattle varied from $0.02 \%$ to $20.6 \%$ (Shmakova, 2019). Our work shows that, on average, cattle are infected in Ukraine with Dicrocoelium lanceatum (18.9\%).

Strongyloidiasis is one of the most common helminthiases of ruminants. Development of Strongyloides spp. to the infective stage takes place in the environment. Animal hosts become infected with infectious larvae when consuming food and water, as well as percutaneously (Boyko et al., 2009, 2019; Boyko \& Brygadyrenko, 2017, 2018, 2019a, 2019b, 2021; Ko et al., 2019). Strongyloides papillosus was the most common in Nige- ria (30.2\%) (Karshima et al., 2018), which is consistent with the data for Ukraine, where $\mathrm{EI}=100 \%$. According to studies in Poltava region, cattle were affected by trichuriasis and fascioliasis, with the average rate of parasite infection at $75.0 \%$, and in sheep the prevalence of strongylatoses of digestive organs and Trichuris did not exceed 20\% (Yevstafieva et al., 2020a). The prevalence of this infection in calves in the Mukurweini district of Kenya was 3.7\% (Peter, 2015). According to the analysis conducted on the territory of Ukraine, the prevalence reached its peak. The causative agents of helminthiasis, according to the analysis of scientific publications, circulate mainly in developing countries, in particular in Africa. A review conducted in Ethiopia presents generalized data on the prevalence of gastrointestinal nematodes in small ruminants. The average prevalence of the infection was $75.8 \%$. At the same time, high heterogeneity was established $\left(\mathrm{I}^{2}=97.8 \%\right)$. Recorded nematode taxa were represented by eleven genera, including Haemonchus, Trichostrongylus, Teladorsagia / Ostertagia, Strongyloides, Bunostomum, Nematodirus, Chabertia, Trichuris, Cooperia, Skrjabinema and Oesophagostomum (Asmare et al., 2016). Sheep in Kumasi (Ghana, Africa) have been studied by a number of other scientists, who found that the most common among parasites were also nematodes of the gastrointestinal tract (EI 94.5\%) of the Strongylata spp. (94.5\%). The second place was taken by Strongyloides helminths (27.3\%) (Owusu et al., 2016). The research data, collected in Burkina Faso, Africa, confirm a high level of prevalence of Strongylata spp. of the gastrointestinal tract $(70.7 \%)$, with a lower rate of monieziasis of sheep (5.7\%). The pathogen Stronyloides spp. had the lowest rate $(0.9 \%)$. The dominant species among nematodes in Kazakh sheep were H. contortus (90.1\%), Trichostrongylus spp. (68.5\%) and Ostertagia spp. (48.9\%) (Yan et al., 2021). Numerous publications confirm the circulation of the causative agent of haemonchosis in China (Britton et al., 2016; Hoberg \& Zarlenga, 2016).

On the island of Bali, Indonesia, the incidence in cattle was $9.3 \%$. The following species have been identified: Paramphistomum spp., Fasciola spp., Bunostomum phlebotomum, Strongyloides papillosus, Trichostrongylus axei and Trichuris ovis. According to the coprooscopic studies of sheep in the autumn-grazing period, in the Poltava region the prevalence of infection of animals by pathogens of parasites reached $100.0 \%$ (Yevstafieva et al., 2020b). The prevalence of nematodes of the genus Trichuris spp. among sheep in the central and south-eastern regions of Ukraine was $65.9 \%$ (Yevstafieva et al., 2018). Three species of Trichuris were found, T. skrjabini Baskakov, 1924, T. ovis Abildgaard, 1795 and T. globulosa Linstow, 1901. Trichuris ovis and T. skrjabini were more common (54.9\% and $35.7 \%)$, whereas $T$. globulosa was relatively rare $(9.4 \%)$.

Thus, gastrointestinal helminths have a significant geographical distribution, including in Ukraine, and we need to summarize the updated data on the distribution to prevent significant economic losses in livestock farms.

\section{Conclusions}

As a result of a meta-analysis of 15 scientific papers, it was found that helminths are quite common in Ukraine, the average prevalence of helminthiases reaching 56.8\% (95\% CI: 56.2-57.3\%). Parasitocenoses are registered more often than monoinfections, and the highest rates of infection prevalence are observed when the species composition includes gastrointestinal strongyles of the order Strongylida. Strongyloides papillosus is the most common of all represented taxa, while Fasciola hepatica has the lowest prevalence.

The application of scientifically based veterinary and sanitary prevention measures on farms of Ukraine, ensuring the effective deworming of livestock, combined with thorough veterinary inspection at meat processing plants would reduce economic losses caused by helminths.

The current studies are the initiative of the authors and do not have any outside financial support. The research was carried out within the framework of the initiative topic for scientific work "Monitoring, improvement of diagnostics, treatment and prevention of invasive diseases of animals of the central part of Ukraine" (state registration No. 0112U001560) 


\section{References}

Abdulhakim, Y., \& Addis, M. (2012). An abattoir study on the prevalence of fasciolosis in cattle, sheep and goats in Debre Zeit town, Ethiopia. Global Veterinaria, $8(3), 308-314$

Aghayan, S., Gevorgian, H., Ebi, D., Atoyan, H. A., Addy, F., Mackenstedt, U., \& Wassermann, M. (2019). Fasciola spp. in Armenia: Genetic diversity in a global context. Veterinary Parasitology, 268, 21-31.

Ahmed, R., Biswas, P., Barua, M., Alim, M., Islam, K., \& Islam, M. (2015). Prevalence of gastrointestinal parasitism of cattle in Banskhali Upazilla, Chittagong, Bangladesh. Journal of Advanced Veterinary and Animal Research, 2(4), 484488

Akca, A., Gokce, H. I., \& Mor, N. (2014). Seroprevalence of Fasciola hepatica infection in cattle and sheep in the province of Kars, Turkey, as determined by ELISA. Helminthologia, 51, 94-97.

Al-Aboody, M. S., \& Omar, M. A. (2016). Prevalence of gastrointestinal nematodes of farm animals by copro-culture. Russian Joumal of Parasitology, 2, 168-174.

Albogami, B. M., Kelany, A. H., \& Abu-Zinadah, O. A. (2015). Prevalence of Dicrocoelium dendriticum infection in sheep at Taif Province, West Saudi Arabia. Journal of the Egyptian Society of Parasitology, 45(2), 435-442.

Ali, Q., Rashid, I., Shabbir, M. Z., Akbar, H., Shahzad, K., Ashraf, K., Sargison, N. \& Chaudhry, U. (2018). First genetic evidence for the presence of the rumen fluke Paramphistomum epiclitum in Pakistan. Parasitology Introduction, 67(5), 533-537.

Amer, S., El-Khatam, A., Zidan, S., Feng, Y., \& Xiao, L. (2016). Identity of Fasciola spp. in sheep in Egypt. Parasites and Vectors, 9(1), 623.

Arbabi, M., Dalimi, A., Ghafarifar, F., \& Foroozandeh Moghadam, M. (2011). Prevalence and intensity of Dicrocoelium dendriticum in sheep and goats of Iran. Research Journal of Parasitology, 6, 160-167.

Arbabi, M., Nezami, E., Hooshyar, H., \& Delavari, M. (2018). Epidemiology and economic loss of fasciolosis and dicrocoeliosis in Arak, Iran. Veterinary World 11(12), 1648-1655.

Arias-Pacheco, C., Lucas, J. R., Rodríguez, A., Cordoba, D., \& Lux-Hoppe, E. G. (2020). Economic impact of the liver condemnation of cattle infected with Fasciola hepatica in the Peruvian Andes. Tropical Animal Health and Production, 52(4), 1927-1932.

Asmare, K., Sheferaw, D., Aragaw, K., Abera, M., Sibhat, B., Haile, A., Kiara, H., Szonyi, B., Skjerve, E., \& Wieland, B. (2016). Gastrointestinal nematode infection in small ruminants in Ethiopia: A systematic review and meta-analysis. Acta Tropica, 160, 68-77.

Ayalew, G., Tilahun, A., Aylate, A., Teshale, A., \& Getachew, A. (2016). A study on prevalence of Paramphistomum in cattle slaughtered in Gondar Elfora Abattoir, Ethiopia. Journal of Veterinary Medicine and Animal Health, 8(8), 107-111.

Ayan, A., Yaman, T., Keleş, Ö., \& Tutun, H. (2019). Examination of some endoparasites prevalence in Romanov sheep imported from Ukraine. Harran Üniversitesi Veteriner Fakültesi Dergisi, 8(1), 99-103.

Beesley, N. J., Caminade, C., Charlier, J., Flynn, R. J., Hodgkinson, J. E., MartinezMoreno, A., Martinez-Valladares, M., Perez, J., Rinaldi, L., \& Williams, D. (2018). Fasciola and fasciolosis in ruminants in Europe: Identifying research needs. Transboundary and Emerging Diseases, 65(Suppl 1), 199-216.

Bennema, S., Vercruysse, J., Claerebout, E., Schnieder, T., Strube, C., Ducheyne, E. Hendrickx, G., \& Charlier, J. (2009). The use of bulk-tank milk ELISAs to assess the spatial distribution of Fasciola hepatica, Ostertagia ostertagi and Dictyocaulus viviparus in dairy cattle in Flanders (Belgium). Veterinary Parasitology, 165, 51-57.

Bohach, M. V., Bohach, T. V., Bondarenko, L. V., \& Piven, O. T. (2015). Vikova dynamika kyshkovykh parazytoziv ovets v hospodarstvakh Odeskoji oblasti [Age dynamics of intestinal parasitosis diseases of sheep on farms in Odessa region]. Problemy Zooinzheneriji ta Veterynarnoji Medytsyny, 30(2), 213-217 (in Ukrainian)

Bojko, O. O. (2015). Gel'mintofauna ovec i kiz [Helmintofauna of sheep and goats in Dnipropetrovsk region]. Visnyk of Dnipropetrovsk University, Biology, Medicine, 6(2), 87-92 (in Ukrainian).

Boyko, A. A., \& Brygadyrenko, V. V. (2017). Changes in the viability of Strongyloides ransomi larvae (Nematoda, Rhabditida) under the influence of synthetic flavourings. Regulatory Mechanisms in Biosystems, 8(1), 36-40.

Boyko, A., Brygadyrenko, V., Shendryk, L., \& Loza, I. (2009). Estimation of the role of antropo-zoonosis invasion agents in the counteraction to bioterrorism. Counteraction to Chemical and Biological Terrorism in East European Countries. NATO Science for Peace and Security Series A: Chemistry and Biology. Springer Nature. Pp. 309-315.

Boyko, O. O., \& Brygadyrenko, V. V. (2018). The impact of certain flavourings and preservatives on the survivability of larvae of nematodes of Ruminantia. Regulatory Mechanisms in Biosystems, 9(1), 118-123.

Boyko, O. O., \& Brygadyrenko, V. V. (2019a). Nematocidial activity of aqueous solutions of plants of the families Cupressaceae, Rosaceae, Asteraceae, Fabaceae, Cannabaceae and Apiaceae. Biosystems Diversity, 27(3), 227-232.
Boyko, O. O., \& Brygadyrenko, V. V. (2019b). The impact of acids approved for use in foods on the vitality of Haemonchus contortus and Strongyloides papillosus (Nematoda) larvae. Helminthologia, 56(3), 202-210.

Boyko, O. O., Gugosyan, Y. A., Shendrik, L. I., \& Brygadyrenko, V. V. (2019). Intraspecific morphological variation in free-living stages of Strongyloides papillosus (Nematoda, Strongyloididae) parasitizing various mammal species. Vestnik Zoologii, 53(4), 313-324

Boyko, O. O., Zazharska, N. M., \& Brygadyrenko, V. V. (2016). Vlijanie urovnia zarazhenija gel'mintami na izmenenije massy tela ovecz v uslovijakh Ukrainy [The influence of the extent of infestation by helminths upon changes in body weight of sheep in Ukraine]. Visnyk of Dnipropetrovsk University, Biology, Ecology, 24(1), 3-7 (in Russian).

Boyko, O., \& Brygadyrenko, V. (2021). Nematicidal activity of essential oils of medicinal plants. Folia Oecologica, 48(1), 42-48.

Britton, C., Roberts, B., \& Marks, N. D. (2016). Functional genomics tools for Haemonchus contortus and lessons from other helminths. Advances in Parasitology, 93, 599-623.

Brown, A. M. D. (2002). Meta-analysis, decision analysis and cost-effectiveness analysis: Methods for quantitative synthesis in medicine. Gastroenterology, 123(2), 650-651.

Chaoudhary, V., Hasnani, J. J., Khyalia, M. K., Pandey, S., Chauhan, V. D., Pandya, S. S., \& Patel, P. V. (2015). Morphological and histological identification of Paramphistomum cervi (Trematoda: Paramiphistoma) in the rumen of infected sheep. Veterinary World, 8(1), 125-129.

Chougar, L., Harhoura, K., \& Aissi, M. (2019). First isolation of Dicrocoelium dendriticum among cattle in some Northem Algerian slaughterhouses. Veterinary World, 12(7), 1039-1045.

Dahourou, L. D., Konaté, A., Tapsoba, A., Dicko, A., Sanou, M., Tamboura, H. H., Bayala, B., Salissou, I., Traoré, A., Logan, L. L., \& Tembely, S. (2021). Epidemiology and spatio-temporal distribution of gastrointestinal parasites infection and accuracy of FAMACHA test in sheep in traditional farming systems in Burkina Faso. Tropical Animal Health and Production, 53(3), 392

Diop, G., Yanagida, T., Hailemariam, Z., Menkir, S., Nakao, M., Sako, Y., Ba, C. T., \& Ito, A. (2015). Genetic characterization of Moniezia species in Senegal and Ethiopia. Parasitology International, 64(5), 256-260.

Elelu, N., \& Eisler, M. C. (2017). A review of bovine fasciolosis and other trematode infections in Nigeria. Journal of Helminthology, 92(2), 128-141.

Gazimagomedov, M. G., \& Ataev, A. M. (2011). Gelminty domashnih zhvachnykh zhivotnykh v Dagestane [Helminths of domestic ruminants in Dagestan]. Rossiyskiy Parazitologicheskiy Zhurnal, 4, 27-30 (in Russian).

Ghanimatdan, M., Chalechale, A., Rezaei, F., Rokni, M. B., \& Shahrokhi, S. R. (2019). Bioclimatic analysis and spatial distribution of livestock fascioliasis in Iran. Iranian Journal of Parasitology, 14(1), 41-51.

Godara, R., Katoch, R., Yadav, A., \& Rastogi, A. (2014). Epidemiology of paramphistomosis in sheep and goats in Jammu, India. Journal of Parasitic Diseases, 38(4), 423-428.

Gorjipoor, S., Moazeni, M., \& Sharifiyazdi, H. (2013). Characterization of Dicrocoelium dendriticum haplotypes from sheep and cattle in Iran based on the internal transcribed spacer 2 (ITS-2) and NADH dehydrogenase gene (nad1). Journal of Helminthology, 89(2), 158-164

Gunathilaka, N., Niroshana, D., Amarasinghe, D., \& Udayanga, L. (2018). Prevalence of gastrointestinal parasitic infections and assessment of deworming program among cattle and buffaloes in Gampaha District, Sri Lanka. BioMed Research International, 2018, 3048373.

Hajipour, N., Mirshekar, F., Hajibemani, A., \& Ghorani, M. (2021). Prevalence and risk factors associated with amphistome parasites in cattle in Iran. Veterinary Medicine and Science, 7, 105-111.

Hanna, R. E. B., Williamson, D. S., Mattison, R. G., \& Nizami, W. A. (1988). Seasonal reproduction in Paramphistomum epiclitum and Gastrothylax crumenifer, rumen paramphistomes of the Indian water buffalo and comparison with the biliary paramphistome Gigantocotyle explanatum. International Journal for Parasitology, 18, 513-521.

Hedges, L. V., \& Vevea, J. L. (1998). Fixed- and random-effects models in metaanalysis. Psychological Methods, 3(4), 486-504.

Higgins, J. P. T., \& Thompson, S. G. (2002). Quantifying heterogeneity in a metaanalysis. Statistics in Medicine, 21, 1539-1558.

Hoberg, E. P., \& Zarlenga, D. S. (2016). Evolution and biogeography of Haemonchus contortus: Linking faunal dynamics in space and time. Advances in Parasitology, 93, 1-30.

Huklaeva, M. G. (2009). Epizootologiya fascioleza zhvachnyih zhivotnyih v Chechenskoy respublike [Epizootology of fasciolosis of ruminants in the Chechen Republic]. Rossiyskiy Parazitologicheskiy Zhurnal, 4, 63-66 (in Russian).

Huson, K. M., Oliver, N. A. M., \& Robinson, M. W. (2017). Paramphistomosis of ruminants: An emerging parasitic disease in Europe. Trends in Parasitology, $33(11), 836-844$

Irie, T., Sakaguchi, K., Ota-Tomita, A., Tanida, M., Hidaka, K., Kirino, Y., Nonaka, N., \& Horii, Y. (2013). Continuous Moniezia benedeni infection in confined 
cattle possibly maintained by an intermediate host on the farm. The Journal of Veterinary Medical Science, 75(12), 1585-1589.

Jaja, I. F., Mushonga, B., Green, E., \& Muchenje, V. (2017). Seasonal prevalence, body condition score and risk factors of bovine fasciolosis in South Africa. Veterinary and Animal Science, 4, 1-7.

Jones, R. A., Brophy, P. M., Mitchell, E. S., \& Williams, H. W. (2017). Rumen fluke (Calicophoron daubneyi) on Welsh farms: Prevalence, risk factors and observations on co-infection with Fasciola hepatica. Parasitology, 144(2), 237-247.

Kahl, A., von Samson-Himmelstjerna, G., Krücken, J., \& Ganter, M. (2021). Chronic wasting due to liver and rumen flukes in sheep. Animals, 11(2), 549.

Karshima, S. N., Maikai, B. V., \& Kwaga, J. (2018). Helminths of veterinary and zoonotic importance in Nigerian ruminants: A 46-year meta-analysis (19702016) of their prevalence and distribution. Infectious Diseases of Poverty, 7(1), 52.

Khademvatan, S., Majidiani, H., Khalkhali, H., Taghipour, A., Asadi, N., \& Yousefi, E. (2019). Prevalence of fasciolosis in livestock and humans: A systematic review and meta-analysis in Iran. Comparative Immunology, Microbiology and Infectious Diseases, 65, 116-123.

Khanjari, A., Bahonar, A., Fallah, S., Bagheri, M., Alizadeh, A., fallah, M., \& Khanjari, Z. (2014). Prevalence of fasciolosis and dicrocoeliosis in slaughtered sheep and goats in Amol Abattoir, Mazandaran, Northern Iran. Asian Pacific Journal of Tropical Disease, 4(2), 120-124.

Ko, P. P., Sakaguchi, K., Yoshida, A., Maruyama, H., Nonaka, N., \& Nagayasu, E. (2019). First molecular identification of Strongyloides vituli in cattle in Japan and insights into the evolutionary history of Strongyloides parasites of ruminants. Parasitology International, 72, 101937

Korchan, L. M. (2015). Poshyrennia dykrotseliozu kiz u Poltavskii oblasti [The spread of dicroceliasis in goats in Poltava region]. Naukovo-Tekhnichnyj Biuleten NDTs Biobezpeky ta Ekolohichnoho Kontroliu Resursiv APK, 3(2), 111-114 (in Ukrainian).

Korchan, L. M., Prykhodko, Y. O., Korchan, M. I., \& Temnyi, M. V. (2015). Poshyrennia trykhurozu kiz u lisostepovij zoni Ukrajiny [The spread of trichuriasis in goats in the forest steppe zone of Ukraine]. Naukovyj Visnyk Lvivskoho Natsionalnoho Universytetu Veterynarnoji Medytsyny ta Biotekhnolohiji imen S. Z. Hzhytskoho, 62, 78-82 (in Ukrainian).

Kruchynenko, O. V., Mykhailiutenko, S. M., Klymenko, O. S., Kanivets, N. S., \& Korchan, L. M. (2020a). Morphological characteristics of Dicrocoelium dendriticum (Digenea, Dicrocoeliidae), parasitizing three host species in the Central Regions of Ukraine. Zoodiversity, 54(5), 403-410.

Kruchynenko, O. V., Prus, M. P., \& Mykhailiutenko, S. M. (2020b). Parazytotsenozy velykoji rohatoji khudoby tsentralnoho rehionu Ukrajiny [Parasitocenoses of cattle in the central region of Ukraine]. Komprynt, Kyiv (in Ukrainian).

Kuerpick, B., Schnieder, T., \& Strube, C. (2012). Seasonal pattern of Fasciola hepatica antibodies in dairy herds in Northern Germany. Parasitology Research, 111, 1085-1092.

Maitra, A., Yadav, C. L., \& Sanjukta, R. K. (2014). Seasonal prevalence of paramphistomosis in domestic ruminants in different agro-climatic zones of Uttarakhand, India. Asian Pacific Journal of Tropical Disease, 4(Suppl. 2), S748-S753.

Majidi-Rad, M., Meshgi, B., \& Bokaie, S. (2018). The prevalence and intensity rate of Dicrocoelium dendriticum infection in ruminants of 3 provinces in coastal regions of the Caspian Sea. Iranian Journal of Veterinary Medicine, 12(1), 27-33.

Maurelli, M. P., Rinaldi, L., Capuano, F., Perugini, A. G., Veneziano, V., \& Cringol, G. (2007). Characterization of the $28 \mathrm{~S}$ and the second internal transcribed spacer of ribosomal DNA of Dicrocoelium dendriticum and Dicrocoelium hospes. Parasitology Research, 101, 1251-1255.

Mehmood, K., Zhang, H., Sabir, A. J., Abbas, R. Z., Jjaz, M., Durrani, A. Z., Saleem, M. H., Ur Rehman, M., Iqbal, M. K., Wang, Y., Ahmad, H. I., Abbas, T., Hussain, R., Ghori, M. T., Ali, S., Khan, A. U., \& Li, J. (2017). A review on epidemiology, global prevalence and economical losses of fasciolosis in ruminants. Microbial Pathogenesis, 109, 253-262.

Melnychuk, V. (2019). Features of seasonal dynamics of sheep haemonchosis in the territory of Zaporizhzhya region. Ukrainian Journal of Veterinary and Agricultural Sciences, 2(2), 7-11.

Melnychuk, V. V. (2019). Epizootychna sytuatsijia shchodo nematodoziv travnoho kanalu ovets v umovakh tsentralnoho ta pivdenno-skhidnoho rehioniv Ukrajiny [Epizootic situation of sheep digestive canal nematodoses in the conditions of the central and south-eastern regions of Ukraine]. Theoretical and Applied Veterinary Medicine, 7(3), 153-157 (in Ukrainian).

Melnychuk, V. V., \& Stepaniuk, V. K. (2016). Vikova dynamika stronhiliatoziv orhaniv travlennia ovets na terytoriji Poltavskoji oblasti [Age dynamics of strongylatoses of the digestive system of sheep in the territory of Poltava region] Bulletin of Poltava State Agrarian Academy, 3, 81-83 (in Ukrainian).

Melnychuk, V., Yevstafieva, V., Bakhur, T., Antipov, A., \& Feshchenko, D. (2020). The prevalence of gastrointestinal nematodes in sheep (Ovis aries) in the central and south-eastern regions of Ukraine. Turkish Journal of Veterinary and Animal Sciences, 44(5), 985-993.

Mirahmadi, H., Bigleri, P., Sekandarpour, S., Modrek, M. J., \& Shafiei, R. (2018) Molecular and phylogenetic characterisation of Fasciola spp. isolated from cat- tle and sheep in Southeastern Iran. Bulgarian Journal of Veterinary Medicine, 21(1), 86-93

Mohamadzadeh, T., Shams, S., Khanaliha, K., Marhamatizadeh, M., \& Vafa, A (2016). A study on prevalence of some helminthic infections of the liver and lungs among ruminants in abattoir of Fars Province, Iran. Archives of Razi Institute, 71(4), 245-251.

Moher, D., Liberati, A., Tetzlaff, J., Altman, D. G., \& PRISMA Group (2009). Preferred reporting items for systematic reviews and meta-analyses: the PRISMA statement. PLoS Medicine, 6(7), e1000097.

Moshfe, A., Rezaei, N., Seyed, A., Cheraghzadeh, S. R., Arefkhah, N., Zare, K. R. Moein, M., P. N., \& Jamshidi, A. (2016). Study on prevalence of fascioliasis in uminants in Dasht Room County in spring and summer of 2013. Animal and Veterinary Sciences, 4(2), 15-18.

Mpofu, T. J., Nephawe, K. A., \& Mtileni, B. (2020). Prevalence of gastrointestinal parasites in communal goats from different agro-ecological zones of South Africa. Veterinary World, 13(1), 26-32.

Naranjo-Lucena, A., Munita Corbalán, M. P., Martínez-lbeas, A. M., McGrath, G., Murray, G., Casey, M., Good, B., Sayers, R., Mulcahy, G., \& Zintl, A. (2018). Spatial patterns of Fasciola hepatica and Calicophoron daubnevi infections in ruminants in Ireland and modelling of C. daubneyi infection. Parasites and Vectors, 11(1), 531 .

Ndom, M., Diop, G., Quilichini, Y., Yanagida, T., Ba, C. T., \& Marchand, B. (2016). Prevalence and scanning electron microscopic identification of anoplocephalic cestodes among small ruminants in Senegal. Journal of Parasitology Research, 2016,3937292

Nguyen, T. D., Le, Q. D., Huynh, V. V., Nguyen, S. T., Nguyen, T. V., \& Vu-Khac, H. (2012). The development of PCR methodology for the identification of species of the tapeworm Moniezia from cattle, goats and sheep in Central Vietnam. Journal of Helminthology, 86(4), 426-429.

Otranto, D., Rehbein, S., Weigl, S., Cantacessi, C., Parisi, A., Lia, R. P., \& Olson, P. D. (2007). Morphological and molecular differentiation between Dicrocoelium dendriticum (Rudolphi, 1819) and Dicrocoelium chinensis (Sudarikov and Ryjikov, 1951) Tang and Tang, 1978 (Platyhelminthes: Digenea). Acta Tropica, 104,91-98.

Owusu, M., Sekyere, J. O., \& Adzitey, F. (2016). Prevalence and burden of gastrointestinal parasites of Djallonke sheep in Ayeduase, Kumasi, Ghana. Veterinary World, 9(4), 361-364

Pavlović, I., Ivanović, S., Ćirković, D., Petrović, M. P., Caro Petrović, V., Maksimović, N., \& Ivanovic, D. (2017). Gastrointestinal helminths of sheep reared in Southwest Serbia. Bulgarian Journal of Veterinary Medicine, 20(1), 402-406.

Peter, G. S., Gitau, G. K., Mulei, C. M., Vanleeuwen, J., Richards, S., Wichtel, J., Uehlinger, F., \& Mainga, O. (2015). Prevalence of cryptosporidia, Eimeria Giardia, and Strongyloides in pre-weaned calves on smallholder dairy farms in Mukurwe-Ini District, Kenya. Veterinary World, 8(9), 1118-1125.

Pinilla León, J. C., Delgado, N. U., \& Florez, A. A. (2019). Prevalence of gastrointestinal parasites in cattle and sheep in three municipalities in the Colombian Northeastern Mountain. Veterinary World, 12(1), 48-54

Pinilla, J. C., Florez Muñoz, A. A., \& Uribe Delgado, N. (2020). Prevalence and risk factors associated with liver fluke Fasciola hepatica in cattle and sheep in three municipalities in the Colombian Northeastern Mountains. Veterinary Parasitology: Regional Studies and Reports, 19, 100364.

Piven, O. T., \& Bogach, M. V. (2016). Poshyrennia zmishanykh kyshkovykh tsestodoziv ovets u hospodarstvakh Odeskoji oblasti [Prevalence of intestinal cestodoses of sheep on farms of Odessa region]. Veterynarna Medytsyna, 102, 176179 (in Ukrainian).

Rinaldi, L., Biggeri, A., Musella, V., de Waal, T., Hertzberg, H., Mavrot, F., Torgerson, P. R., Selemetas, N., Coll, T., Bosco, A., Grisotto, L., Cringoli, G., \& Catelan, D. (2015). Sheep and Fasciola hepatica in Europe: The GLOWORM experience. Geospatial Health, 9(2), 309-317.

Ruano, Z., Cortinhas, A., Carolino, N., Gomes, J., Costa, M., \& Mateus, T. (2020). Gastrointestinal parasites as a possible threat to an endangered autochthonous Portuguese sheep breed. Journal of Helminthology, 94, e103.

Sanguankiat, S., Sato, M. O., Sato, M., Maipanich, W., Yoonuan, T., Pongvongsa, T., Boupha, B., Chigusa, Y., Moji, K., \& Waikagul, J. (2016). First record of paramphistomes Fischoederius cobboldi and Paramphistomum epiclitum detected in bovine rumen from a local market of Savannakhet Province, Lao PDR. Korean Journal of Parasitology, 54(4), 543-547.

Sargeant, J. M., \& O'Connor, A. M. (2020). Scoping reviews, systematic reviews, and meta-analysis: Applications in veterinary medicine. Frontiers in Veterinary Sciencet, 7, 11

Scala, A., Tamponi, C., Dessì, G., Sedda, G., Sanna, G., Carta, S., Corda, A., Jacquiet, P., Varcasia, A., \& Ligios, C. (2019). Dicrocoeliosis in extensive sheep farms: A survey. Parasites and Vectors, 12(1), 342.

Shamsi, L., Samaeinasab, S., \& Samani, S. T. (2020). Prevalence of hydatid cyst, Fasciola spp. and Dicrocoelium dendriticum in cattle and sheep slaughtered in Sabzevar Abattoir, Iran. Annals of Parasitology, 66(2), 211-216.

Shmakova, O. N. (2019). Rasprostranenie dikrocelioza v populyaciyah krupnogo rogatogo skota i maralov na territoriji Altajskogo kraya [Expansion of dicroceli- 
osis in cattle and maral population on the Altai territory]. Vestnik Ulyanovskoj Gosudarstvennoj Selskokhozyajstvennoj Akademii, 45, 70-74 (in Russian).

Siben, A. N., Domatsky, V. N., Nikonov, A. A., \& Beletskaya, N. I. (2018). Analiz rasprostraneniya fasczioleza krupnogo rogatogo skota $\mathrm{v}$ Tyumenskoj oblasti [The analysis of distribution of cattle fascioliasis in Tyumen oblast]. Ukrainian Journal of Ecology, 8(1), 832-837 (in Russian).

Soosaraei, M., Fakhar, M., Teshnizi, S. H., Emameh, R. Z., Hezarjaribi, H. Z., Asfaram, S., Faridnia, R., \& Kalani, H. (2020). Status of fasciolosis among domestic ruminants in Iran based on abattoir data: A systematic review and meta-analysis. Annals of Parasitology, 66(1), 77-86.

Soroka, N. M. (2020). Perebih trykhurozu yak parazytozu orhaniv travlennia ovets [The course of trichuriasis as parasitosis of the sheep digestive system]. Bulletin of Poltava State Agrarian Academy, 1, 148-153 (in Ukrainian).

Soroka, N. M., Bilopolska, T. P., \& Pashkevych, I. Y. (2015). Dykrotselioz velykoji rohatoji khudoby [Dicrocoeliasis of cattle]. Komprynt, Kyiv (in Ukrainian).

Soroka, N. M., Ovcharuk, N. P., \& Pashkevych, I. Y. (2017). Shlunkovo-kyshkovi stronhiliatozy velykoji rohatoji khudoby [Gastrointestinal strongylatosis of cattle]. Komprynt, Kyiv (in Ukrainian).

Squire, S. A., Yang, R., Robertson, I., Ayi, I., Squire, D. S., \& Ryan, U. (2018). Gastrointestinal helminths in farmers and their ruminant livestock from the Coastal Savannah zone of Ghana. Parasitology Research, 117(10), 3183-3194.

Taye, M., Jagema, T., Tadese, A., Mulatu, E., Lelisa, K., \& Damena, D. (2016). Study of ruminant fasciolosis in selected districts in Upper Awash River Basin, South Westem Shoa, Ethiopia. Journal of Veterinary Science and Technology, 2016, 368 .

Toolan, D. P., Mitchell, G., Searle, K., Sheehan, M., Skuce, P. J., \& Zadoks, R. N. (2015). Bovine and ovine rumen fluke in Ireland - prevalence, risk factors and species identity based on passive veterinary surveillance and abattoir findings. Veterinary Parasitology, 212, 168-174.

Uddin, M. Z., Farjana, T., Begum, N., \& Mondal, M. M. H. (2006). Prevalence of amphistomes in black Bengal goats in Mymensingh District. Bangladesh Journal of Veterinary Medicine, 4, 103-106.

Yan, X., Liu, M., He, S., Tong, T., Liu, Y., Ding, K., Deng, H., \& Wang, P. (2021). An epidemiological study of gastrointestinal nematode and Eimeria coccidia infections in different populations of Kazakh sheep. PloS One, 16(5), e0251307.

Yevstafieva, V. A Yuskiv, I. D., Melnychuk, V. V., Yasnolob, I. O, Kovalenko, V.A., \& Horb, K. O. (2018). Nematodes of the genus Trichuris (Nematoda, Trichuridae) parasitizing sheep in central and south-eastern regions of Ukraine. Vestnik Zoologii, 52(3), 193-204.

Yevstafieva, V., Kruchynenko, O., Melnychuk, V., Mykhailiutenko, S., Korchan, L., Shcherbakova, N., \& Dolhin, O. (2020a). Epizootolohichni osoblyvosti perebihu parazytoziv u velykoji rohatoji khudoby ta ovets u litnio-pasovyshchnyj period [Epizootological peculiarities of the course of cattle and sheep parasitoses in the summer pasture period]. Bulletin of Poltava State Agrarian Academy, 3, 205-212.

Yevstafieva, V., Kruchynenko, O., Melnychuk, V., Mykhailiutenko, S., \& Korchan, L. (2020b). Osoblyvosti poshyrennia parazytoziv ovets u osinnio-pasovyshchnyj period [Peculiarities of sheep parasitoses spreading in the autumn-pasture period]. Bulletin of Poltava State Agrarian Academy, 4, 163-169.

Yuan, W., Liu, J.-M., Lu, K., Li, H., Duan, M.-M., Feng, J.-T., \& Lin, J.-J. (2016) Molecular identification and seasonal infections of species of Fasciola in ruminants from two provinces in China. Journal of Helminthology, 90(3), 359-363. 